\title{
Synthesis and optimization of combustion of briquettes based on substandard brown coals of Kazakhstan deposits with multipolymer binders
}

\author{
Marat Tulepov ${ }^{1,2}$, Larissa Sassykova ${ }^{1,2, *}$, Dauren Baiseitov ${ }^{1,2}$, Bibigul Rakhimova ${ }^{1,2}$, Fedosya \\ Abdrakova ${ }^{1,2}$, Galiya Spanova ${ }^{1}$, Sestager Aknazarov ${ }^{1,2,3}$ and Zhansaya Beksultan 1,2 \\ ${ }^{1}$ Faculty of Chemistry and Chemical Technology, Al-Farabi Kazakh National University, \\ 71, al-Farabi ave., 050040, Almaty, Kazakhstan. \\ ${ }^{2}$ The Combustion Problems Institute, 172, Bogenbai batyr str., 050012, Almaty, Kazakhstan. \\ ${ }^{3}$ Scientific and Production Technical Center “Zhalyn” LLP, 172, Bogenbai Batyr str., \\ 050012, Almaty, Kazakhstan.
}

\begin{abstract}
The work aimed to study the process of burning coal briquettes with polymers. As the object of the research, the coals of Kazakhstan deposits were applied. The methodology of the study included theoretical and computational studies on the applied significance of coal processing, analysis by physicochemical research methods, pressing, drying and briquetting of coal with binders. It is shown that the briquettes combustion takes place stepwise and is characterized by a stationary regime. This is due to the mutual influence of the stages of pyrolysis of polyolefins and combustion of coke residue of substandard coal. In the combustion zone, the temperature did not depend on the content of polyethylene and was $400-500^{\circ} \mathrm{C}$ in the coal burnout zone. The optimal compositions of briquettes supporting the combustion temperature of $1300^{\circ} \mathrm{C}$ were determined: coal- 40 $\%$, clay-20\%, polyethylene-40\%. Adding up to $20 \%$ clay to the polymer and coal mixture led to the formation of a combustion wave structure with symmetric temperature profiles. Thermogravimetric analysis shows that polyethylene plays the role of the initiator of combustion, burning at $500^{\circ} \mathrm{C}$, and in the future does not affect the maintenance of the combustion temperature of the briquette. The perspective of the results obtained is the possibility of utilization of low-demand coals of various brands of Kazakhstan deposits, which are waste of coal mining and coal enrichment with further production of coal briquettes of the required quality. Coal briquettes made from substandard coals with a multi-polymer binder, from chemical production waste have a higher calorific value, are mechanically robust during prolonged storage, do not crumble in the furnace until complete combustion, and are waterproof. These advantages determine their use for the population, as well as for various purposes of industrial economy, metallurgy and chemical industry.
\end{abstract}

Keywords: coal; briquetting; binder; tar; calorific value; energy performance.

\section{Introduction}

Coal reserves in Kazakhstan are currently estimated at 33 billion tons, which is about $4 \%$ of the world reserves. Of these, more than $60 \%$ are brown coal deposits, and just under $40 \%$ are coal reserves ${ }^{1-4}$. The oldest and most common is the use of coal as a fuel for combustion ${ }^{2-5}$. It is well known that more than $60 \%$ of coal can be lost in the form of coal fines. Notable quantity of coal fines can be lost during transportation. Coal fines are located in necessary amounts at coal mines, at transhipment points and, very often, they can be placed in the useful areas, pose a significant threat of pollution of the nearest territory. Massive losses in coal mining lead to the search for additional types of work on the processing of coal fines ${ }^{5-9}$. Based on the description *Corresponding author: Larissa Sassykova

Email address: larissa.rav@mail.ru

DOI: http://dx.doi.org/10.13171/mjc020032712531s of the chemical composition and physical properties of coal, it can be concluded that existing methods for using coal do not allow to realize its raw material and energy potential fully. At the same time, brown coals, according to their technical characteristics, have less attractiveness, which predetermines their additional pretreatment.

For this reason, there is a need to create briquettes from coal fines, which is an urgent task in the regions of coal production ${ }^{10-13}$. The problem of coal briquetting is one of the most important for many enterprises of the coal industry. Producing coal briquettes is one of the most perspective solutions for recycling non-standard coal and coal fines. Briquetting makes it possible to dispose of unclaimed small coal fractions, improve the quality

Received January 7, 2020

Accepted March 2, 2020

Published March 27, 2020 
and thermal characteristics of the fuel as a result of briquetting with a significant increase in the completeness of combustion, reduce environmental pollution ${ }^{6,14-19}$.

To obtain strong briquettes, various cementing substances of organic and inorganic nature are added to coal fines: for example, resin, dextrin, lime, asphalt, molasses, soluble glass, soda, clay, alum, cement ${ }^{20-23}$. The obtained mass is firmly pressed. The principle of selecting a mixture of particles of different sizes of optimal bulk density is based on the theory of the densest packing of grains. If the sieve composition of the charge is improperly selected or if it is poorly prepared, the space between the grains of coal is filled with a binder or its mixture with small grains of coal. Also, the necessary bond between the coal grains is broken, which makes it impossible to obtain briquettes of the required strength. The technology of coal briquetting without binding additives seems more attractive at first glance, but several times increase the cost of electricity, decrease the productivity and quality of briquette ${ }^{24-28}$.

The purpose of this work was to study the combustion process of coal briquettes with components of organic origin. The objects of research for the production of briquettes from coal and polymers were the coals of Kazakhstan deposits.

\section{Experimental}

Coal briquettes were synthesized based on substandard coal of deposits Shubarkol, Karazhira and Oi Karagay of Central region of Kazakhstan. First, mixtures of solid polymer residues were subjected to preliminary heat treatment, after which they were machined to a particle size> $200 \mathrm{~m}$ together with coal. The prepared mixtures were carefully stored with safety precautions to protect against oxidation, possible sources of pollution, which may be reagents, atmosphere, dust.

For briquetting, an automated hydraulic press was used. Pressing was carried out in closed cylindrical dies with a diameter of 10 to $25 \mathrm{~mm}$. The necessary ingredients for briquetting of coal were mixed in a specific sequence until a homogeneous mass was obtained. Then briquetting was carried out in a press at a pressing pressure coinciding with the demand in industrial roll presses $(25 \mathrm{MPa})$. To give the necessary plasticity of the mixture and dilute the binder, water was added to the mixture before briquetting. The strength of the briquettes was determined by crushing on the IP-100 press with the control of the maximum force that the briquette can withstand. Determination of strength characteristics was carried out after cooling briquettes to room temperature.

Heat treatment of briquettes was carried out in special cabinets with controlled temperature in the range of $50-400^{\circ} \mathrm{C}$. The combustion temperature was measured by Raytek $3 \mathrm{i} 1 \mathrm{M}$ optical pyrometer. The surface and structure of the studied carbon materials were determined using a Ntegra Therma scanning electron microscope.

Coal briquettes were obtained by standard technology 21,23,29-31, consisting of the processes of coal grinding, drying it to the desired moisture content, mixing it with necessary cementers (polystyrene foams, polyethylene terephthalate (PET) or polyethylene (Fig.1). Polyethylene and PET were preliminarily heated, then crushed, mixed with coal and pressed.

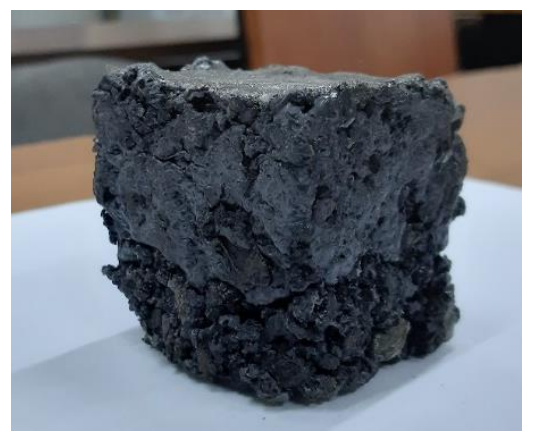

Figure 1. The appearance of the resulting coal briquette

\section{Results and Discussion}

According to its mechanical properties (melting, density, brittleness), the foam refers to polymers with a low density. It has a certain degree of branching, while polyethylene and PET have a higher density, in which the linear polymer chains are more densely packed ${ }^{32-34}$ (Table 1 ). Obviously, for polymers, the experimentally measured melting point is not a strict characteristic, as for low molecular weight crystalline bodies. The melting temperature of polymers is directly dependent on density. The higher the density, the higher the melting point.

It was revealed that the specificity of polymer melting lies in the fact that this phase transition is observed in a rather broad temperature range (from 150 to $445^{\circ} \mathrm{C}$ ). In this study, the melting temperature was estimated as the temperature corresponding to the middle of the melting range, i.e. before it transitioned to a liquid state. 
Thus, the main factors determining the melting point of the polymer are the chemical structure, molecular weight characteristics and crystallization conditions. It is known that the ignition temperature $\mathrm{T}_{\mathrm{i}}$, the solid combustion cessation temperature $\mathrm{T}_{\mathrm{b}}$ and the maximum temperature $\mathrm{T}_{\max }$ can be determined by thermogravimetric analysis (TGA) ${ }^{21-22,28,30}$. The shape of the TGA curves primarily depends on such kinetic parameters as the reaction order, preexponential factor, and activation energy. These parameters are of paramount importance for elucidating the mechanism of thermal decomposition of polymers since they determine the temperature characteristics.

Table1. Technical characteristics of polymers.

\begin{tabular}{|c|c|c|c|c|}
\hline Polymers & $\begin{array}{c}\text { Softening } \\
\text { temperature, } \\
\mathrm{T}_{\text {softening, }}{ }^{\circ} \mathrm{C}\end{array}$ & $\begin{array}{c}\text { The melting } \\
\text { temperature, } \\
\mathrm{T}_{\text {melting }},{ }^{\circ} \mathrm{C}\end{array}$ & $\begin{array}{c}\text { Fragility in liquid } \\
\text { nitrogen, } \\
\mathrm{T}_{\text {fragility }}{ }^{\circ} \mathrm{C}\end{array}$ & $\begin{array}{c}\text { Density, } \\
\rho, \mathrm{g} / \mathrm{cm}^{3}\end{array}$ \\
\hline Polyethylene & 100 & $110-375$ & -70 & 9.3 \\
\hline Polyfoam (polystyrene) & 80 & $100-250$ & - & 4.3 \\
\hline Polyethylene Terephthalate (PET) & 260 & $350-445$ & -60 & 13.4 \\
\hline
\end{tabular}

Fig.2 and Fig. 3 show thermogravimetric curves for briquettes with polystyrene foam and polyethylene.

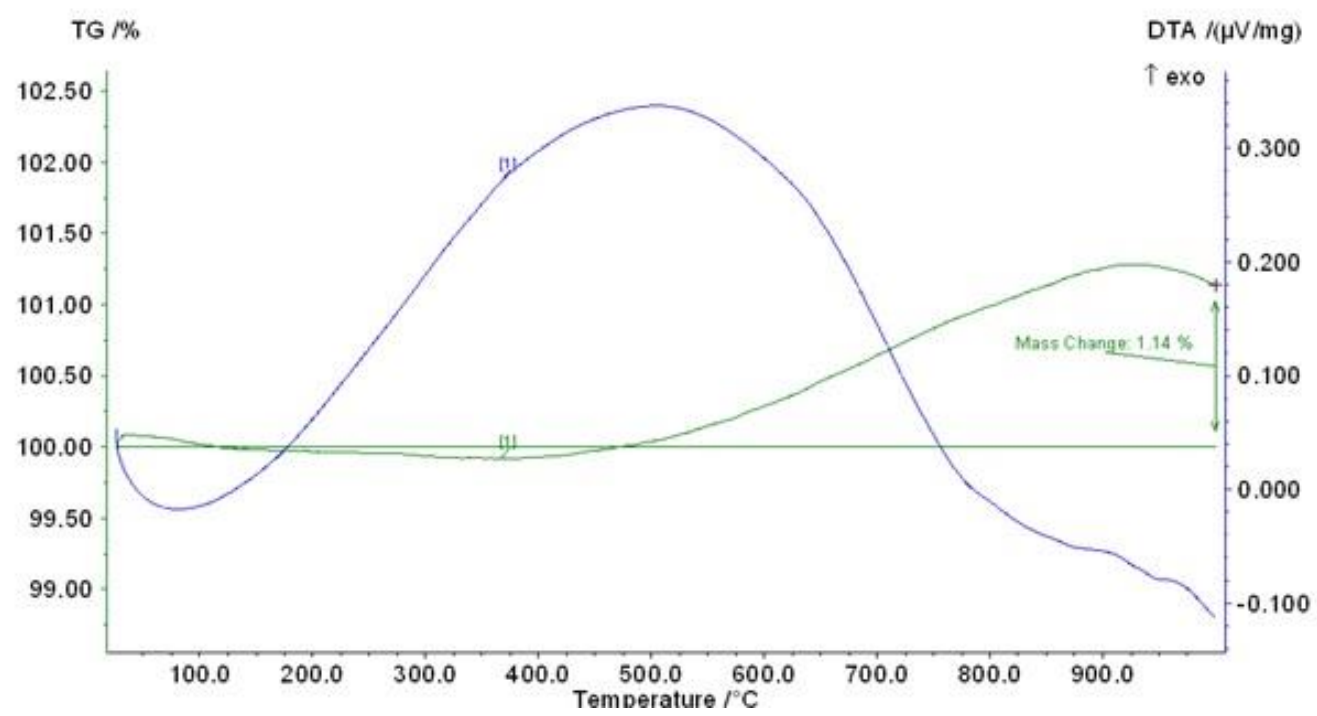

Figure 2. Thermogravimetric curve of the decomposition of the briquette with foam

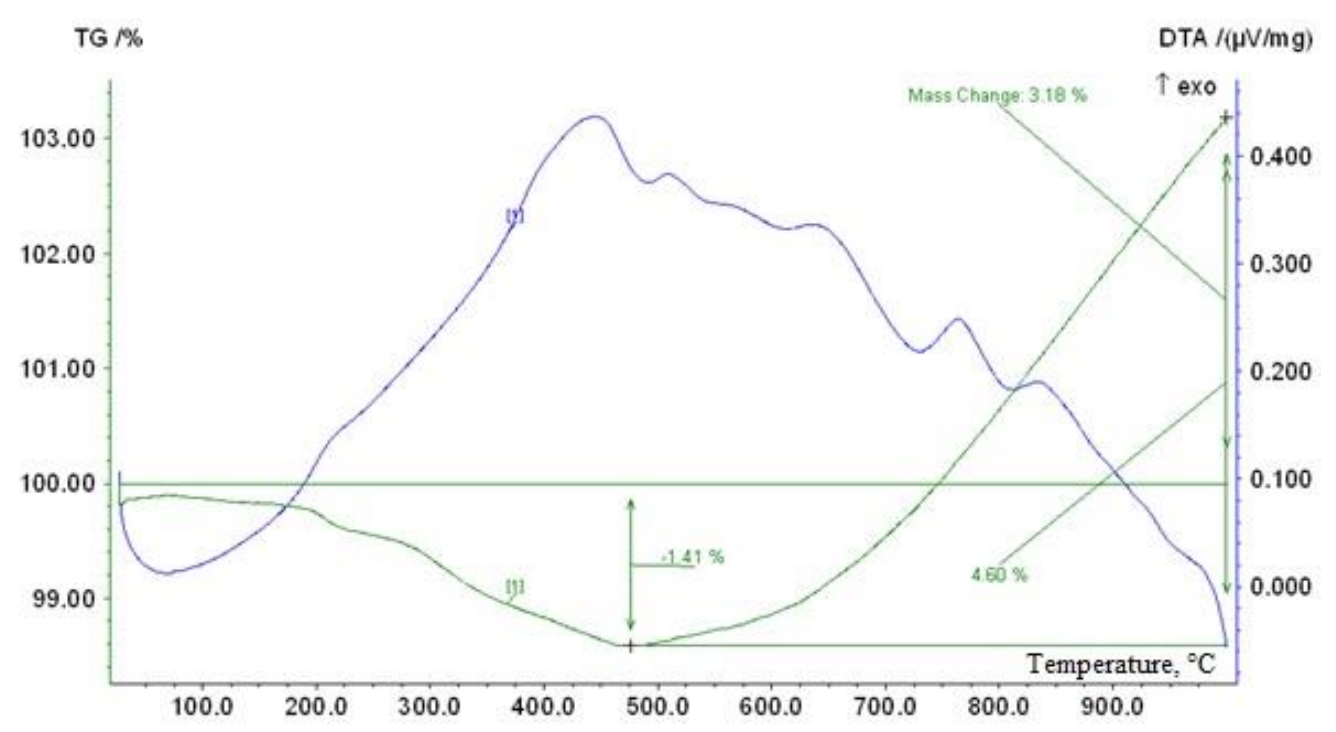

Figure 3. Thermogravimetric curve of the decomposition of coal with polyethylene 
The curves obtained using TGA in a system with polyethylene (Fig.2) showed that in endothermic reactions, the differential curve deviates from the zero lines down. In exothermic reactions, it deviates from the zero line up ${ }^{35-37}$. The magnitude of the deviation (temperature peak) characterizes the degree of difference in the temperature of the phase transitions. It is an indicator of the amount of transformed substance and the intensity of the reaction. As can be seen from Fig.2, the phase transformation curve assumes moisture loss at $100^{\circ} \mathrm{C}$, then $\mathrm{T}_{\max }=500^{\circ} \mathrm{C}$. It is known that the maximum of the differential curve of mass loss corresponds to the maximum speed of any process that occurs when exposed to temperature, and is equal to $50 \%$ mass loss.

Thus, the method of the thermogravimetric analysis showed that in the case of phase transformation of polyethylene (Fig.3), processes are observed that lead to both an endothermic and an exothermic effect. Heat exchange is a determining factor in the energy characteristics of briquettes. From a comparison of Fig.2 and Fig.3, it is clear that the thermal destruction of the composition with polyethylene occurs with heat absorption. From this, we can conclude that coal briquettes with polyethylene act as inhibitors in the composition of the briquette, which determines not only the phase transformation procedure but also the overall combustion process of the whole composition ${ }^{38-40}$.
From these curves, it can be seen that the foam with the briquette decomposes with the formation of one phase component at a temperature of $500^{\circ} \mathrm{C}$ (Fig.2). In the case of polyethylene, the temperature of phase transformations occurs stepwise (Fig.3). This is probably due to a higher degree of branching of the polymer chain, and a higher proportion of reactive tertiary carbon atoms from coal and polymer appears to initiate the degradation stage.

It was found that in both cases the polyolefins burn entirely out and evaporate at temperatures above $523-559^{\circ} \mathrm{C}$. Then, the remaining carbon residues are decomposed. According to the weight loss of the TGA curves, it can be assumed that the evaporation of polyethylene begins at temperatures close to $350-500^{\circ} \mathrm{C}$, the breaking of polyolefin chains starts at lower temperatures at the foam $250-385^{\circ} \mathrm{C}$. This is due to the decomposition of the whole polymer chain with the simultaneous release of some gaseous products ${ }^{41,42}$.

The combustion processes of briquettes with foam and polyethylene with the removal of the temperature characteristics by a pyrometer were studied (Fig.4). It is established that the burning of briquettes with components of organic origin is stepwise and is not characterized by a stationary mode. This is due to the mutual influence of the pyrolysis stages of polyolefins and the burning out of the coke residue of substandard coal.

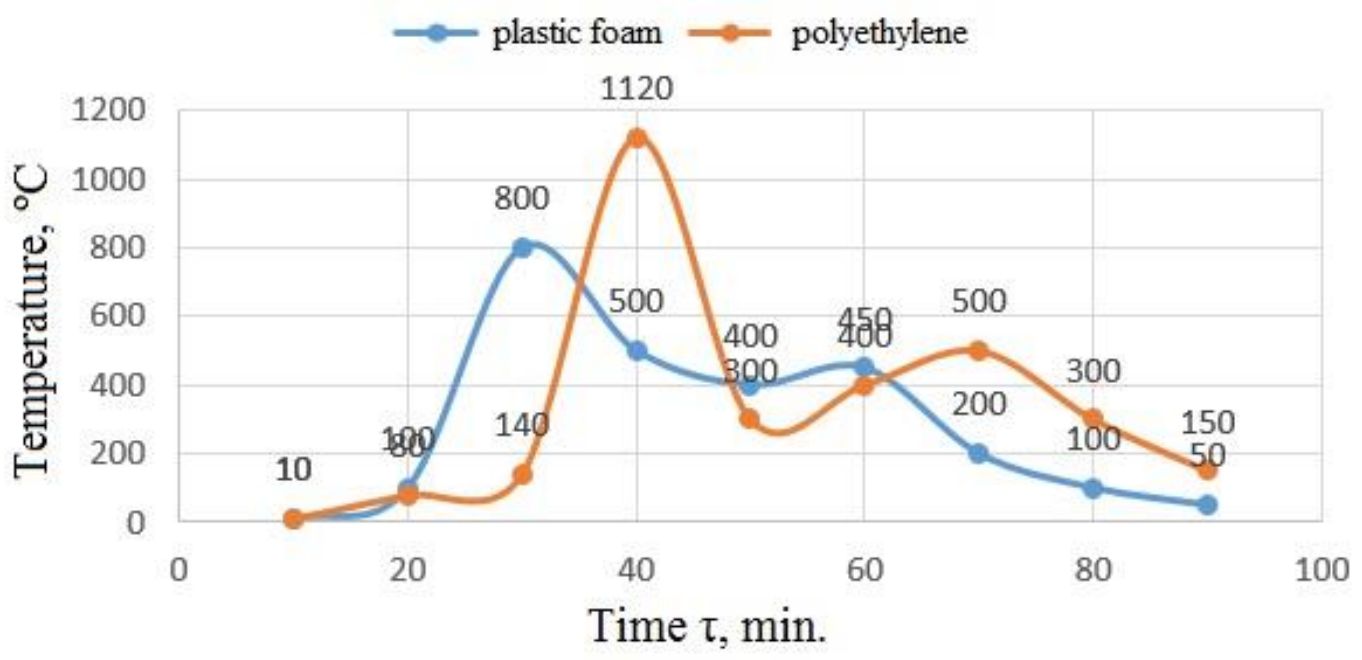

Figure 4. The temperature profile of the combustion of briquettes with polyethylene and foam

During the combustion of mixtures of polymers with coal, the structure of the combustion wave was first characterized by a high leading combustion front and a relatively smooth decrease in temperature beyond the combustion zone ${ }^{43,44}$. In the combustion zone, polyethylene pyrolysis and oxidation of degradation products of coal macromolecules took place simultaneously, due to which a rather high temperature was maintained in the combustion front (Fig.5). The temperature did not depend on the content of polyethylene and amounted to $400-500^{\circ} \mathrm{C}$ in the zone of burning out of coal. 


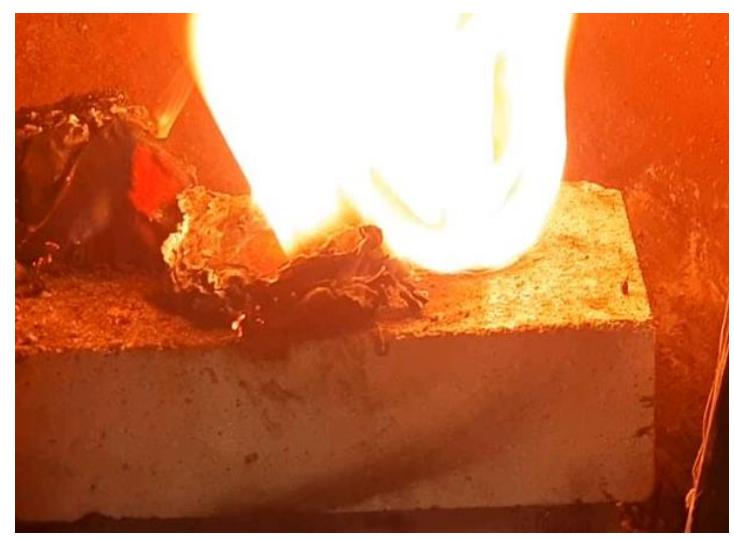

Figure 5. Burning briquette with foam

Since coal with polymer had a low calorific value, clay in the briquettes (Fig.6). experiments were carried out with the addition of

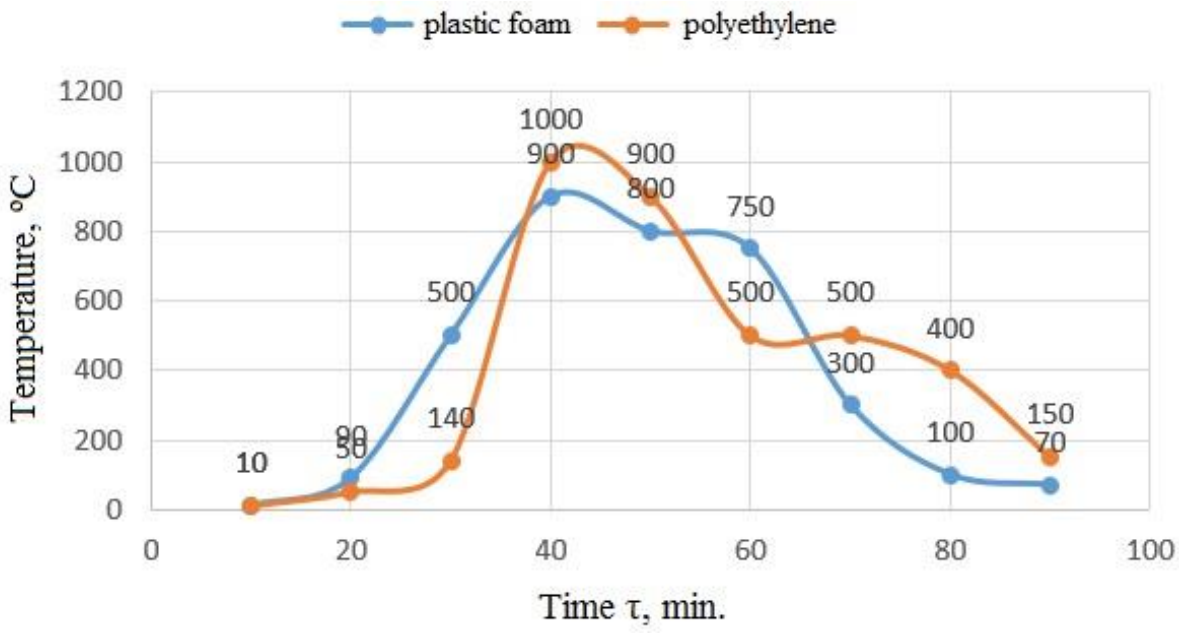

Figure 6. Burning temperature profile of briquettes with polyethylene and foam in the presence of $10 \%$ clay

When $10 \%$ clay was added to the mixture of polymers and coal, the thermal structure of the combustion wave remained constant. In contrast, the maximum wave temperature did not depend on the content of polymers in the mixture and was approximately $1000^{\circ} \mathrm{C}$. According to the pyrometer, the temperature profiles were more symmetrical compared with the case of mixtures without adding clay. Adding up to $20 \%$ clay to the polymer and coal mixture led to the formation of a combustion wave structure with symmetric temperature profiles.

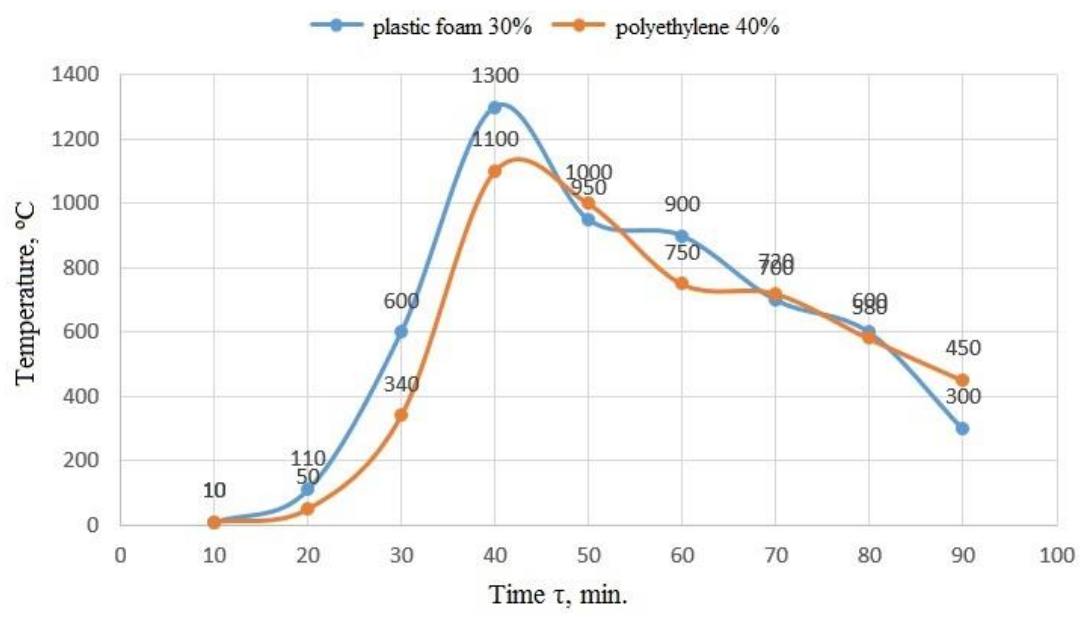

Figure 7. The combustion temperature profile of briquettes with $40 \%$ polyethylene and $30 \%$ poly styrene in the presence of $30 \%$ clay 
With an increase in the polymer content from 10 to $40 \%$ (Fig.7), the maximum temperature in the combustion wave reached approximately $1300^{\circ} \mathrm{C}$. When burning mixtures of polymers with clay and $70 \%$ coal, the process characteristics were also practically independent of the polymer content. The maximum combustion temperature in the entire range of changes in the proportion of polymers was $1300^{\circ} \mathrm{C}$. The temperature profile also had a symmetrical appearance.

\section{Conclusion}

The problem of coal briquetting is one of the most important for many enterprises of the coal industry. Producing coal briquettes is one of the most perspective solutions for recycling non-standard coal and coal fines. In this work, the combustion processes of coal briquettes based on substandard coal of Kazakhstan deposits with foam and polyethylene are investigated. It was revealed that the burning of briquettes with components of organic origin occurs stepwise and is not characterized by a stationary mode, which is due to the mutual influence of the pyrolysis stages of polyolefins and the burning of coke residue of substandard coal. The combustion temperature of the briquettes was independent of the content of polyethylene and amounted to $400-500^{\circ} \mathrm{C}$ in the zone of coal burning. According to the TGA, polyethylene played the role of a combustion initiator, burned out at $500^{\circ} \mathrm{C}$, and subsequently did not affect the maintenance of the combustion temperature of the briquette. The optimal composition of briquettes that maintain a burning temperature of $1300^{\circ} \mathrm{C}$ was as follows: coal$40 \%$, clay- $20 \%$, polyethylene- $40 \%$. The results of the study showed that multipolymer binders can be used not only as a binder in the synthesis of briquettes but also supply hydrocarbons that are actively involved in oxidative processes. Such hydrocarbons increase the exothermicity of the combustion reaction, and also ultimately improve the characteristics of coal and their energy potential. Elaboration briquetting technology based on the local sub-standard coals makes it possible to dispose of unclaimed small coal fractions, improve the quality and thermal characteristics of the fuel with a significant increase in the completeness of combustion, reduce environmental pollution.

\section{Acknowledgements}

The work was carried out under the project IRN AP05131088 "Development of technology of preparation of brown coal briquettes of substandard coal with a multi polymer binder" under the program: 217 "Development of science" subprogram: 102 "Grant financing of scientific research" of the Committee of Science of MES RK.

\section{References}

1- D. A. Baiseitov, M. I. Tulepov, L. R. Sassykova, Sh. E. Gabdrashova, A. N. Magazova, O. Dalelkhanuly, Zh. B. Kudyarova, Z. A. Mansurov, Catalytic hydrogenation of coal of the Kazakhstan fields in the presence of polymers, Bulg. Chem. Comm., 2017, 3, 600.

2- V. Popovych, A. Voloshchyshyn, Features of temperature and humidity conditions of extinguishing waste heaps of coal mines in spring, News of the National Academy of Sciences of the Republic of Kazakhstan, series of geology and technology sciences, 2019, 436, 230-237.

3- http://uglex.com/articles/232-zapasy-uglya-vkazakhstane.html.

4- Concept of development of the coal industry of the Republic of Kazakhstan for the period until 2020. Texture. Kazakhstan, Astana:b.i., 2008, 78.

5- M. Tulepov, Z. Mansurov, L. Sassykova, D. Baiseitov, O. Dalelhanuly, Zh. Ualiev, Sh. Gabdrashova, Zh. Kudyarova, Research of ironcontaining concentrates of Balkhash deposit (Kazakhstan) for processing of low-grade coal, Journal of Chemical Technology and Metallurgy, 2019, 54, 531-538.

6- T. Olugbade, O. Ojo, T. Mohammed, Influence of binders on combustion properties of biomass briquettes: a recent review, Bioenergy Research, 2019, 12, 241-259.

7- B. T. Yermagambet, N. U. Nurgaliyev, N. A. Maslov, L. D. Abylgazina, A. A. Syzdykov, Effect of electrophysical impact on the physical and chemical characteristics of coal ash from the Maikuben deposit, News of the National Academy of Sciences of the Republic of Kazakhstan, series of geology and technology sciences, 2020, 439, 38-47. https://doi.org/10.32014/2020.2518-170X.5

8- V. S. Yemelyanova, B. T. Dossumova, T. V. Shakiyeva, L. R. Sassykova, S. Sendilvelan, Processing fly ash from the thermal power stations for gas emissions purification from sulfur dioxide, International Journal of Mechanical and Production Engineering Research and Development, 2019, 9, 1027-1036.

9- D. A. Baiseitov, Sh. E. Gabdrashova, A. N. Magazova, O. Dalelkhanuly, Zh. B. Kudyarova, M. I. Tulepov, L. R. Sassykova, Z. A. Mansurov, Hydrogenation of coal of "Karazhira" field: optimal catalysts and thermogravimetric researches, Int. J. Chem. Sci., 2016, 14, 244.

10-T. Das, B. K. Saikia, D. K. Dutta, D. Bordoloi, B. P. Baruah, Agglomeration of low rank Indian coal fines with an organic binder and the thermal behavior of the agglomerate produced: Part I, Fuel, 2015, 147, 269-278.

11-G. R. Nyssanbayeva, K. K. Kudaibergenov, A. K. Seidildayeva, L. R. Sassykova, M. I. Tulepov, Synthesis of modified nanocarbon materials and 
determination of their adsorption capacity, International Journal of Mechanical and Production Engineering Research and Development, 2020, 10, 305-314.

12-L. Makouki, M. Tarbaoui, S. Glissi, S. Mansouri, H. Hannache, M. Oumam, Applying Response Surface Methodology to optimize the decarbonization process of Timahdit oil shale, Mediterranean Journal of Chemistry, 2019, 8, 372-379.

13-S. R. Motaung, S. J. Mangena, G. J. de Korte, R. I. McCrindle, J. H. P. van Heerden, Effects of Coal Composition and Flotation Reagents on the Water Resistance of Binderless Briquettes, Coal Preparation, 2007, 27, 230-248.

14-G. G. Stevenson, R. D. Perlack, The prospects for coal briquetting in the Third World, Energy Policy, 1989, 17, 215-227.

15-D. Baiseitov, M. Tulepov, L. Sassykova, Sh. Gabdrashova, K. Kudaibergenov, Z. Mansurov, Physicomechanical properties of petrosorbents of the phytogenesis, Rev. Roum. Chim., 2017, 62, 249-253.

16-D. Fatimah, L. M. Estiaty, Coal blending preparation for non-carbonized coal briquettes, Proceedings of the IOP Conference Series: Earth and Environmental Science, 2017, 118, conference 1, https://doi.org/10.1088/17551315/118/1/012068.

17-P. Caputo, G. A. Ranieri, N. Godbert, I. Aiello, A. Tagarelli, C. O. Rossi, Investigation of new additives to reduce the fume emission of bitumen during Asphalt Concrete Processing, Mediterranean Journal of Chemistry, 2018, 7, 259-266.

18-G. K.Ngusale, Y. Luo, J. K. Kiplagat, Briquette making in Kenya: Nairobi and peri-urban areas, Renewable and Sustainable Energy Reviews, 2014, 40, 749-759.

19-M. Meincken, S. Funk. Burning characteristics of low-cost safety charcoal briquettes made from wood residues and soil for domestic use, Agroforestry Systems, 2015, 89, 357-363.

20-J. Shen, Reaction mechanism of co processing coal and heavy oils, Coal conversion, 1999, 22, 5-8.

21-Zh. Tashmukhambetova, Y. Aubakirov, Zh. Shomanova, K. Burkhanbekov, R. Safarov, L. Sassykova, N. Zhakirova, M. Faizullaeva, The effects of pretreatment methods of carboncontaining wastes in thermal catalytic recycling, Oriental Journal of Chemistry, 2017, 33, 2884-2890. http://dx.doi.org/10.13005/ojc/330622.

22-R. Yan, H. Zhu, Ch. Zheng, M. Xu, Emissions of organic hazardous air pollutants during Chinese coal combustion, Energy, 2002, 27, 485- 503. https://doi.org/10.1016/s0360-5442(02)00003-8.

23-M. I. Tulepov, L. R. Sassykova, A. R. Kerimkulova, G. O. Tureshova, D. M. Tolep, A. O. Zhapekova, G. A.Spanova, F. Yu. Abdrakova, Z. A. Mansurov, Preparation of coal briquettes and determination of their physical and chemical properties, Orient J. Chem., 2018, 35, 180-185.

24-D. A. Baiseitov, Sh. E. Gabdrashova, A. K. Akylbai, O. Dalelkhanuly, Zh. B. Kudyarova, L. R. Sassykova, M. I. Tulepov, Z. A. Mansurov, Obtaining of liquid fuel from coal in the presence of the polymers, Int. J. Chem. Sci., 2016, 14, 261-268.

25-A. S. Maloletnev, O. A. Mazneva, K.I. Naumov, Mechanochemical activation of coal from the Erkovetskoe deposit and its reactivity in a liquefaction process, Solid Fuel Chemistry, 2015, 49, 372.

26-G. J. de Korte, Processing low-grade coal to produce high-grade products, Journal of the Southern African Institute of Mining and Metallurgy, 2015, 115, 569-572.

27-G. Borowski, J. J. Hycnar, Utilization of Fine Coal Waste as a Fuel Briquettes, International Journal of Coal Preparation and Utilization, 2013, 33, 194-204.

28-A. S. Maloletnev, A. M. Gyul'maliev, Structure of coal hydrogenation products obtained in the presence of oil and coal paste-forming agents, Solid Fuel Chemistry, 2013, 47, 231-233.

29- V. Yu. Bazhin, V. B. Kuskov, Production of fuel briquettes from carbon-containing materials, Proceedings of the XVIII International Coal Preparation Congress, Saint-Petersburg, Russia, 2016, 701-705. https://doi.org/10.1007/978-3319-40943-6_108.

30-V. S. Yemelyanova, B. T. Dossumova, T. V. Shakiyeva, L. R. Sassykova, S. Sendilvelan, Modified aluminosilicate catalysts based on cenospheres of power plants for processing fuel oil into light fractions, International Journal of Mechanical and Production Engineering Research and Development, 2019, 9, 1079-1086.

31-S. Nomura, Coal briquette carbonization in a slottype coke oven, Fuel, 2016, 185, 649-655. https://doi.org/10.1016/j.fuel.2016.07.082.

32-D. Taulbee, D. P. Patil, Rick Q. Honaker, B. K. Parekh, Briquetting of Coal Fines and Sawdust Part I: Binder and Briquetting-Parameters Evaluations, International Journal of Coal Preparation and Utilization, 2009, 29, 1-22.

33-A. Demirbas, Sustainable Charcoal Production and Charcoal Briquetting, Energy Sources, Part A: Recovery, Utilization, and Environmental Effects, 2009, 31, 1694-1699.

34-G. Lu, Y. Yan, M. Colechin, R. Hill, Monitoring of oscillatory characteristics of pulverized coal flames through image processing and spectral analysis, IEEE Transactions on Instrumentation and Measurement, 2006, 55, 226 - 231.

35-Q. Zhong, Y. Yang, T. Jiang, Q. Li, B. Xu, Xylene activation of coal tar pitch binding characteristics for the production of metallurgical quality briquettes from coke breeze, Fuel 
Processing Technology, 2016, 148, 12-18. https://doi.org/10.1016/j.fuproc.2016.02.026.

36-S. E. Gabdrashova, N. M. Rakhova, I. O. Pustovalov, Zh. Elemesova, M. I. Tulepov, M. A. Korchagin, L. R. Sassykova, S. Sendilvelan, D. A. Baiseitov, Preparation of mechanically activated mixtures of Titanium with the carbon nanotubes and study of their properties under thermal explosion, Rasayan J. Chem., 2018, 11, 324-330.

37-N. Skoczylas, B. Dutka, J. Sobczyk, Mechanical and gaseous properties of coal briquettes in terms of outburst risk, Fuel, 2014, 134, 45-52.

38-M. J. Blesa, J. L. Miranda, M. T. Izquierdo, R. Moliner, Curing temperature effect on the mechanical strength of smokeless fuel briquettes prepared with molasses, Fuel, 2003, 82, 943-947.

39-Y. A. Abakr, A. E. Abasaeed, Experimental evaluation of a conical screw briquetting machine for the briquetting of carbonized cotton stalks in Sudan, Journal of Engineering Science and Technology, 2006, 1, 212- 220.
40-M. J. Antal, M. Grønli, The art, science, and technology of charcoal production, Industrial \& Engineering Chemistry Research, 2003, 42, 1619-1640.

41-M. A. Somerville, The strength and density of green and reduced briquettes made with iron ore and charcoal, Journal of Sustainable Metallurgy, 2016, 2, 228-238.

42-Binder for improving coal gangue and low-grade coal, Fuel and Energy Abstracts, 2002, 43, 10.

43-T. S. Manina, N. I. Fedorova, S. A. Semenova, Z. R. Ismailov, Processing low-grade oxidized coal to produce effective carbon sorbents, Coke and Chemistry, 2012, 55, 115-118.

44- V. Zubkova, A. Strojwas, M. Strojanowska, J. Kowalczyk, The influence of the composition of coal briquettes on changes in the volume of the heated coal charge, Fuel Processing Technology, 2014, 128, 265-275. https://doi.org/10.1016/j.fuproc.2014.07.022. 